\title{
ANALISIS PENDEKATAN SAINTIFIK PADA KURIKULUM 2013 DI SDN TANJUNGREJO 1 MALANG
}

\author{
Nury Yuniasih \\ Universitas Kanjuruhan Malang \\ E-mail: nury_yuniasih@yahoo.com \\ Iskandar Ladamay, Dyah Tri Wahyuningtyas
}

\begin{abstract}
ABSTRAK: Penelitian ini bertujuan untuk mendeskripsikan implementasi pendekatan saintifik dalam pembelajaran tematik terpadu kurikulum 2013 di SDN Tanjungrejo 1 Malang. Subjek penelitian ini adalah guru dan siswa kelas I dan IV SDN Tanjungrejo 1 Malang. Pendekatan penelitian yang digunakan adalah penelitian kualitatif dengan metode penelitian studi kasus. Teknik pengumpulan data yang digunakan pada penelitian ini meliputi: wawancara mendalam, observasi, dan dokumentasi. Data dianalisis melalui reduksi data, penyajian data, dan verifikasi. Hasil penelitian menunjukkan bahwa pembelajaran dengan mengimplementasikan pendekatan saintifik telah dilaksanakan dengan baik oleh guru kelas 1 dan guru kelas 4 SDN Tanjungrejo 1 Malang. Hal ini terbukti dengan cara guru mengelola metode saintifik tidak berurutan dan disesuaikan dengan kebutuhan siswa sehingga pembelajaran tidak terkesan sempit dan kaku. Kemampuan berpikir ilmiah siswa juga mengalami peningkatan. Hal ini terlihat dari kemampuan siswa dalam menalar, menemukan, menciptakan, hingga mengkomunikasikan suatu karya. Sehingga dapat disimpulkan kreatifitas guru yang menentukan keberhasilan pembelajaran dengan pendekatan saintifik ini. Disarankan kepada guru untuk mengembangkan kreatifitas terutama dalam mengelola metode pembelajaran, agar pembelajaran dengan mengimplementasikan pendekatan saintifik ini menjadi pembelajaran yang bermakna.
\end{abstract}

Kata kunci: Pendekatan saintifik, Kurikulum 2013

\begin{abstract}
This study aimed to describe the implementation of a scientific approach to learning integrated thematic curriculum in 2013 at SDN Tanjungrejo 1 Malang. The subjects were teachers and students of class I and IV SDN Tanjungrejo 1 Malang. The research approach used is qualitative research with case study method. Data collection techniques used in this study include: in-depth interviews, observation, and documentation. Data were analyzed through data reduction, data presentation, and verification. The results showed that learning by implementing the scientific approach has been implemented properly by the teacher grade 1 and grade 4 teacher SDN Tanjungrejo 1 Malang. This is evident by the way teachers manage the scientific method is not sequential and adapted to the needs of students so that learning does not seem cramped and stiff. Scientific thinking skills of students also increased. It is seen from the students' skills in reasoning, find, create, to communicate a work. Therefore we can conclude that the success of the creativity of teachers teaching with this scientific approach. It is recommended to teachers to develop creativity, especially in managing learning methods, so learning to implement this scientific approach into meaningful learning.
\end{abstract}

Keywords: scientific approach, Curriculum 2013

Salah satu cara meningkatkan kualitas pendidikan di Indonesia adalah dengan perubahan dan perbaikan kurikulum. Kurikulum di Indonesia telah mengalami perubahan hingga 11 kali setelah Indonesia merdeka pada tahun 1945, yaitu pada tahun 1947, 1952, 1964, 1968,
1975, 1984, 1994, 2004, 2006 dan tahun 2013. Perubahan kurikulum ini disesuaikan tuntutan dan perubahan yang terjadi di masyarakat dalam sistem politik, sosial budaya, ekonomi dan iptek.

Perubahan kurikulum yang ke-11 terjadi pada pertengahan tahun 2014 dari KTSP 2006 
menjadi Kurikulum 2013. Alasan perubahan kurikulum ini untuk mendorong siswa melakukan observasi, bertanya, bernalar, dan mengkomunikasikan (mempresentasikan) dari apa yang mereka peroleh setelah menerima materi pembelajaran. Adapun obyek yang menjadi pembelajaran dalam penataan dan penyempurnaan kurikulum 2013 menekankan pada fenomena alam, sosial, seni, dan budaya. Melalui pendekatan tersebut diharapkan siswa memiliki kompetensi sikap, keterampilan, dan pengetahuan jauh lebih baik. Mereka akan lebih kreatif, inovatif, dan lebih produktif, sehingga nantinya mereka bisa sukses dalam menghadapi berbagai persoalan dan tantangan di zamannya, memasuki masa depan yang lebih baik (Kemendikbud, 2013: 1).

Berdasarkan alasan tersebut kurikulum 2013 dikembangkan dengan pendekatan ilmiah atau disebut dengan pendekatan saintifik. Pendekatan saintifik merupakan pendekatan yang dirancang sedemikian rupa agar siswa secara aktif mengonstruksi konsep, hukum atau prinsip melalui tahapan-tahapan mengamati (untuk mengidentifikasi atau menemukan masalah), merumuskan masalah, mengajukan atau merumuskan hipotesis, mengumpulkan data dengan berbagai teknik, menganalisis data, menarik kesimpulan dan mengomunikasikan konsep, hukum atau prinsip yang ditemukan (Machin, 2014: 28).

Tujuan pembelajaran pada kurikulum 2013 mengimplementasikan pendekatan saintifik didasarkan pada keunggulan pendekatan tersebut, antara lain: (1) meningkatkan kemampuan intelek, khususnya kemampuan berpikir tingkat tinggi (berpikir ilmiah), (2) untuk membentuk kemampuan siswa dalam menyelesaikan suatu masalah secara sistematik (problem solving), (3) terciptanya kondisi pembelajaran dimana siswa merasa bahwa belajar itu merupakan suatu kebutuhan, (4) diperolehnya hasil belajar yang tinggi, (5) untuk melatih siswa dalam mengomunikasikan ide-ide, khususnya dalam menulis artikel ilmiah, dan (6) untuk mengembangkan karakter siswa (Machin, 2014: 28-29).
Pola pikir ilmiah dalam pendekatan saintifik diwujudkan dengan mengimplementasikan metode mengamati, menanya-mempertanyakan, menalar-mencipta, mencoba, dan mengkomunikasikan dalam pembelajaran. Langkah-langkah berpikir ini harus dikembangkan guru dalam pembelajaran. Oleh sebab itu, Pola pikir ilmiah tersebut hendaknya tidak langsung digunakan guru dalam proses pengembangan kompetensi siswa sebab jika diterima secara kaku langkah-langkah berpikir tersebut akan menjadi begitu sempit dan kaku (Akbar, 2014: 1).

Implementasi pendekatan saintifik di SDN Tanjungrejo 1 Malang dilaksanakan pada kelas 1 dan 4. Guru kelas 1 dan 4 menyatakan bahwa telah mengimplementasikan pendekatan saintifik dalam pembelajaran. Guru kelas 1 menegaskan proses berpikir ilmiah siswa sulit terwujud karena beberapa siswa belum menguasai keterampilan dasar menulis, membaca dan berhitung. Guru kelas 4 menegaskan proses berpikir ilmiah terlihat dari semakin tingginya antusias siswa dalam pembelajaran. Hasil observasi proses pembelajaran yang dilakukan peneliti pada kelas 1 dan kelas 4 menunjukkan guru melakukan pembelajaran sesuai dengan apa yang ada pada buku guru dan buku siswa kurikulum 2013. Proses pembelajaran yang dilaksanakan menunjukkan kegiatan siswa mendominasi dalam pembelajaran, akan tetapi proses berpikir ilmiah belum sepenuhnya terjadi.

Berdasarkan hasil wawancara dan observasi tersebut, perlu adanya analisis pembelajaran yang dilakukan oleh guru apakah sudah mengimplementasikan pendekatan saintifik dengan benar. Oleh sebab itu tujuan dari penelitian ini adalah untuk mengetahui: (a) implementasi pendekatan saintifik kurikulum 2013 di SDN Tanjungrejo 1 Malang. (b) kesiapan guru kelas 1 dan 4 mengimplementasikan pendekatan saintifik dalam pembelajaran. (c) tanggapan siswa kelas 1 dan 4 dalam pembelajaran yang meng-implementasikan pendekatan saintifik. (d) kendala dalam 
mengimplementasikan pendekatan saintifik dalam pembelajaran

\section{LANDASAN TEORI}

Peraturan Menteri Pendidikan Dan Kebudayaan No. 65 Tahun 2013 tentang standar proses pendidikan dasar dan menengah menegaskan bahwa prinsip pembelajaran yang digunakan pada kurikulum 2013 dari pendekatan tekstual menuju proses sebagai penguatan penggunaan pendekatan ilmiah/pendekatan saintifik. Kurikulum 2013 bertujuan untuk membentuk siswa yang mandiri dalam mencari tahu/menemukan konsep serta menuju pembelajaran yang jawaban kebenarannya bukan jawaban tunggal melainkan multi dimensi. Oleh sebab itu, pendekatan yang berawal dari pendekatan tekstual menuju proses sebagai penguatan penggunaan pendekatan ilmiah.

Pembelajaran yang menggunakan pendekatan ilmiah /saintifik adalah pembelajaran yang dirancang secara prosedural sesuai dengan langkah-langkah umum kegiatan ilmiah. Pada pembelajaran, pendekatan saintifik diimplementasikan dalam kegiatan yaitu mengamati, menanya, mencoba, menalar, dan mengomunikasikan (Kurikulum, 2013: 3). Menurut Machin (2014: 28) Pembelajaran melalui pendekatan saintifik adalah proses pembelajaran yang dirancang sedemikian rupa agar siswa secara aktif mengkonstruksi konsep, hukum atau prinsip melalui tahapan-tahapan mengamati (untuk mengidentifikasi atau menemukan masalah), merumuskan masalah, mengajukan atau merumuskan hipotesis, mengumpulkan data dengan berbagai teknik, menganalisis data, menarik kesimpulan dan mengomunikasikan konsep, hukum atau prinsip yang ditemukan. Berdasarkan penjelasan tersebut dapat disimpulkan bahwa pembelajaran saintifik adalah pembelajaran yang bertujuan untuk mengembangkan pola berpikir ilmiah siswa dengan cara mengimplementasikan metode mengamati, menanya, mencoba, menalar, dan mengomunikasikan dalam pembelajaran.
Karakteristik pembelajaran yang mengimplementasikan pendekatan saintifik sesuai dengan Standar Kompetensi Lulusan, sasaran pembelajaran mencakup pengembangan ranah sikap, pengetahuan, dan keterampilan yang dielaborasi untuk setiap satuan pendidikan. Ketiga ranah kompetensi tersebut memiliki lintasan perolehan (proses psikologis) yang berbeda. Sikap diperoleh melalui aktivitas“ menerima, menjalankan, menghargai, menghayati, dan mengamalkan". Pengetahuan diperoleh melalui aktivitas" mengingat, memahami, menerapkan, menganalisis, mengevaluasi, mencipta. Keterampilan diperoleh melalui aktivitas" mengamati, menanya, mencoba, menalar, menyaji, dan mencipta" (Kurikulum, 2013: 3)..

Karakteristik kompetensi beserta perbedaan lintasan perolehan (proses psikologis) turut serta mempengaruhi karakteristik standar proses. Untuk memperkuat pendekatan ilmiah (scientific), tematik terpadu (tematik antarmata pelajaran), dan tematik (dalam suatu mata pelajaran) perlu diterapkan pembelajaran berbasis penyingkapan/penelitian (discovery/inquiry learning). Untuk mendorong kemampuan siswa untuk menghasilkan karya kontekstual, baik individual maupun kelompok maka sangat disarankan menggunakan pendekatan pembelajaran yang menghasilkan karya berbasis pemecahan masalah(project based learning) (Kurikulum, 2013: 3).

Sejalan dengan penegasan tersebut penerapan pendekatan saintifik/ilmiah dalam pembelajaran menuntut adanya perubahan setting dan bentuk pembelajaran tersendiri yang berbeda dengan pembelajaran konvensional. Beberapa metode pembelajaran yang dipandang sejalan dengan prinsip-prinsip pendekatan saintifik/ ilmiah, antara lain metode: (1) Problem Based Learning; (2) Project Based Learning; (3) Inkuiri/Inkuiri Sosial; dan (4) Group Investigation. Metode-metode ini berusaha membelajarkan siswa untuk mengenal masalah, merumuskan masalah, mencari solusi atau menguji jawaban sementara atas suatu masalah/pertanyaan dengan melakukan penyelidikan 
(menemukan fakta-fakta melalui penginderaan), pada akhirnya dapat menarik kesimpulan dan menyajikannya secara lisan maupun tulisan (Sudrajat, 2013: 1).

Berdasarkan karakteristik tersebut pendekatan saintifik sangat sesuai dalam meningkatkan kemampuan berpikir ilmiah siswa dengan tahapan-tahapan pembelajarannya. Selain itu, ketiga ranah dalam sasaran pembelajaran yang meliputi: pengetahuan, sikap dan keterampilan juga mengalami pengembangan karena metode saintifik mengajarkan siswa belajar mandiri dan belajar mengembangkan kemampuan diri. Kemandirian dan bentuk pengembangan diri siswa dapat tercermin dari tahapan pembelajaran berikut, (1) mengenal masalah yang termasuk dalam proses mengamati jika dipandang dari ranah keterampilan, (2) merumuskan masalah dan mencari solusi dengan cara mencari fakta-fakta termasuk dalam proses memahami jika dipandang dari ranah pengetahuan, (3) mengatasi masalah yang termasuk dalam proses menjalankan jika dipandang dari ranah sikap. Sesuai dengan tahapan pembelajaran tersebut di dalamnya terdapat ketiga ranah yang dipandang dari segi saintifik seperti, mengamati, memahami, dan menjalankan yang saling berkesinambungan satu sama lain.

Dalam proses pembelajaran metode saintifik yang dikembangkan oleh guru meliputi lima metode yaitu, mengamati, menanya, mencoba, menalar, dan mengomunikasikan yang tercermin dalam ranah keterampilan. Akan tetapi, bukan berarti ranah sikap dan pengetahuan tidak akan muncul, kedua ranah tersebut akan tetap masuk dalam kegiatan pembelajaran karena ketiga ranah saling berkesinambungan satu sama lain. Kelima metode tersebut dikembangkan dalam pembelajaran sesuai dengan kreatifitas guru. Pengembangan pembelajaran tidak mewajibkan guru menggunakan metode secara berurutan karena jika dilaksanakan secara beurutan pembelajaran akan menjadi sempit dan kaku. Jika pembelajaran luwes dan mudah dipahami maka akan terwujud pembelajaran yang bermakna (Akbar, 2014: 1).

\section{METODE}

Penelitian ini menggunakan pendekatan kualitatif dengan jenis penelitian studi kasus. Bogdan dan Taylor dalam Moleong (2011:4) menyatakan bahwa penelitian kualitatif adalah prosedur penelitian yang menghasilkan data deskriptif berupa kata-kata tertulis atau lisan dari orang-orang dan perilaku yang dapat diamati. Pendekatan kualitatif ini diarahkan pada latar dan individu secara holistik (utuh). Orang-orang dalam definisi yang dinyatakan oleh Bogdan dan Taylor yakni orang-orang yang diwawancara, diobservasi, diminta memberikan data, pendapat, pemikiran, dan persepsinya secara individual dan kelompok. Penelitian kualitatif ini berjenis studi kasus karena peneliti menyelidiki secara cermat suatu peristiwa, aktivitas, proses terhadap obyek yang diteliti.

Sejalan dengan pendapat Bogdan dan Taylor, Sugiyono (2010:306) menyatakan peneliti kualitatif sebagai human instrumen, berfungsi menetapkan fokus penelitian, memilih informan sebagai sumber data, melakukan pengumpulan data, menilai kualitas data, analisis data, menafsirkan data dan membuat kesimpulan atas temuannya. Dalam penelitian kualitatif segala sesuatu yang akan dicari dari obyek penelitian belum jelas dan pasti masalahnya, sumber datanya, hasil yang diharapkan semuanya belum jelas. Rancangan penelitian masih bersifat sementara dan akan berkembang setelah peneliti memasuki obyek penelitian. Selain itu dalam memandang realitas, penelitian kualitatif berasumsi bahwa realitas itu bersifat holistik (menyeluruh), dinamis, tidak dapat dipisah-pisahkan ke dalam variabel-variabel penelitian. Kalaupun dapat dipisah-pisahkan, variabelnya akan banyak sekali. Dengan demikian dalam penelitian kualitatif ini belum dapat dikembangkan instrumen penelitian sebelum masalah yang diteliti jelas sama sekali. Jadi peneliti adalah merupakan instrumen kunci dalam penelitian kualitatif. Berdasarkan 
pendapat para ahli dapat disimpulkan bahwa penelitian kualitatif merupakan penelitian yang mengkaji data berupa kata-kata tertulis maupun lisan dari obyek penelitian secara holistik (utuh), dinamis dan saling berkaitan antara variabel satu dengan variabel yang lain.

Sugiyono (2010:298-299) menjelaskan bahwa penelitian kualitatif tidak menggunakan populasi, karena penelitian kualitatif berangkat dari kasus tertentu yang ada pada situasi sosial tertentu dan hasil kajiannya tidak akan diberlakukan ke populasi, tetapi ditransferkan ke tempat lain pada situasi sosial yang memiliki kesamaan dengan situasi sosial pada kasus yang dipelajari. Sampel dalam penelitian kualitatif bukan dinamakan responden, tetapi sebagai nara sumber, atau partisipan, informan, teman dan guru dalam penelitian. Sampel dalam penelitian kualitatif, juga bukan disebut sampel statistik, tetapi sampel teoritis, karena tujuan penelitian kualitatif adalah untuk menghasilkan teori. Pada penelitian kualitatif, peneliti memasuki situasi sosial yang dapat berupa lembaga pendidikan tertentu, melakukan observasi dan wawancara kepada orang-orang yang dipandang tahu tentang situasi sosial tersebut. Sumber data dalam penelitian ini adalah kepala sekolah, guru dan siswa SDN Tanjungrejo 1 Malang.

Dalam penelitian ini pengumpulan data dilakukan dengan (1) observasi partisipasif, Partisipasi aktif dipilih menjadi jenis observasi partisipasif dalam penelitian ini. Partisipasi aktif yakni dalam observasi ini peneliti ikut melakukan apa yang dilakukan nara sumber, tetapi tidak sepenuhnya lengkap. Peneliti dalam mengumpulkan data ikut observasi partisipasif dalam beberapa kegiatan, tetapi tidak semuanya. (2) wawancara mendalam, merupakan percakapan untuk menggali informasi sebanyakbanyaknya dari informan yang bertujuan untuk memperoleh konstruksi yang terjadi tentang orang, kejadian, aktivitas organisasi, perasaan, motivasi dan pengetahuan seseorang tentang pengalamannya,dan (3) dokumentasi, studi dokumentasi pada penelitian ini sebagai pelengkap dari observasi dan wawancara agar data lebih kredibel dan sebagai bukti pelaporan bahwa penelitian ini benar-benar dilaksanakan.

Langkah-langkah yang dilakukan selama proses analisis data pada penelitian ini adalah sebagai berikut: (1) Reduksi Data (Data Reduction), Kehadiran peneliti dalam lokasi penelitian yang lama dan proses pengambilan data melalui beberapa teknik mengakibatkan data yang diperoleh semakin banyak dan rumit. Untuk itu diperlukan reduksi data agar bisa memilah dan memilih data yang diperlukan atau relevan dengan fokus penelitian yang telah ditentukan. (2) Penyajian Data (Data Display), Sugiyono (2010:341) bahwa yang paling sering digunakan untuk menyajikan data dalam penelitian kualitatif adalah dengan teks yang bersifat naratif. (3) Verifikasi (Conclusion Drawing), penarikan verifikasi dan penarikan kesimpulan. Data-data yang telah diperoleh peneliti dari observasi, wawancara dan dokumentasi secara tidak langsung peneliti sudah menemukan kesimpulan untuk fokus penelitian yang telah ditentukan. Kesimpulan sementara yang telah ditemukan oleh peneliti akan diverifikasi dengan mencari bukti-bukti yang lebih valid dan konsisten sehingga kesimpulan tersebut merupakan kesimpulan yang kredibel.

\section{HASIL DAN PEMBAHASAN \\ Hasil}

Berdasarkan hasil penelitian diketahui bahwa Implementasi pendekatan saintifik pada kurikulum 2013 di kelas 1 dan 4 di SDN Tanjungrejo 1 pelaksanaannya disesuaikan dengan kaidah pendekatan saintifik yang mencakup lima metode yaitu: mengamati, menanya-mempertanyakan, menalar-mencipta, mencoba, dan mengomunikasikan. Implementasikan pendekatan saintifik pada kelas 1 tergambar pada proses pembelajaran yang ada pada tabel 1 berikut ini:

\section{Tabel 1 Kegiatan Pembelajaran Kelas 1}

\begin{tabular}{ll}
\hline \multicolumn{1}{c}{ Kegiatan Pembelajaran } & Metode \\
\hline $\begin{array}{l}\text { Siswa mengajukan pertanyaan } \\
\text { berkaitan dengan cerita tentang } \\
\text { kegiatan di musim kemarau }\end{array}$ & Menanya \\
\hline $\begin{array}{l}\text { Siswa diminta mengamati gambar } \\
\text { berlibur ke pantai yang ada di }\end{array}$ & Mengamati \\
\hline
\end{tabular}




\begin{tabular}{ll}
\hline \multicolumn{1}{c}{ Kegiatan Pembelajaran } & \multicolumn{1}{c}{ Metode } \\
\hline buku teks & \\
\hline $\begin{array}{l}\text { Siswa diminta menyebutkan } \\
\text { benda apa saja yang terdapat pada } \\
\text { gambar }\end{array}$ & Menalar \\
\hline $\begin{array}{l}\text { Siswa diminta untuk menggambar } \\
\text { benda yang digunakan saat musim } \\
\text { kemarau }\end{array}$ & Mencoba \\
\hline $\begin{array}{l}\text { Siswa diminta untuk menjelaskan } \\
\text { hasil menggambarnya di depan } \\
\text { kelas }\end{array}$ & $\begin{array}{l}\text { Mengkomuni- } \\
\text { kasikan }\end{array}$ \\
\hline
\end{tabular}

Berdasarkan tabel 1 di atas dapat disimpulkan bahwa pembelajaran di kelas 1 telah sesuai dengan kaidah pendekatan saintifik. Pembelajaran yang dilaksanakan guru dan siswa kelas 1 meliputi proses mempertanyakan, mengamati, menalar-mencipta, mencoba, dan mengkomunikasikan. Setelah guru menceritakan sebuah cerita tentang kegiatan di musim kemarau siswa mengajukan pertanyaan " $\mathrm{Bu}$, kegiatan apa yang bisa dilakukan ketika musim kemarau?". Ketika siswa menanyakan hal tersebut guru memberikan kegiatan supaya siswa dapat menemukan jawaban dari pertanyaannya itu sendiri. Kegiatan yang dilakukan oleh siswa adalah mengamati gambar keluarga yang sedang berlibur di pantai, menemukan benda apa saja yang terdapat pada gambar, menggambar benda yang digunakan pada musim kemarau, dan terakhir siswa diminta untuk menjelaskan hasil gambarnya di depan kelas. Setelah itu guru membimbing siswa menyimpulkan kegiatan yang dilakukan pada saat musim kemarau salah satunya adalah bermain di pantai.

Proses berpikir ilmiah yang tergambar di atas terjadi disetiap kegiatan dan siswa sendiri yang melakukannya. Siswa sangat aktif dalam menemukan jawaban dari pertanyaannya sendiri dan guru bertugas membimbing dan mengarahkan pembelajaran. Proses menemukan jawaban ini merupakan salah satu bentuk usaha dalam berpikir secara ilmiah. Walaupun siswa kelas 1 kemampuan berpikirnya masih di tingkat rendah, tetapi mereka dapat menyimpulkan kegiatan dan menemukan jawaban secara mandiri. Sehingga dapat disimpulkan proses berpikir ilmiah juga dapat dilakukan oleh siswa kelas 1 Sekolah Dasar.
Selain dilaksanakan pada kelas 1, Implementasikan pendekatan saintifik juga dilaksanakan di kelas 4. Proses pembelajaran pada kelas 4 tergambar pada tabel 2 berikut ini:

\section{Tabel 2 Kegiatan Pembelajaran Kelas 4}

\begin{tabular}{ll}
\hline \multicolumn{1}{c}{ Kegiatan Pembelajaran } & \multicolumn{1}{c}{ Metode } \\
\hline $\begin{array}{l}\text { Siswa mengajukan pertanyaan } \\
\text { tentang sumber bunyi }\end{array}$ & Menanya \\
\hline $\begin{array}{l}\text { Siswa mengamati sumber bunyi } \\
\text { yang ditunjukkan guru }\end{array}$ & Mengamati \\
\hline $\begin{array}{l}\text { Siswa diminta melakukan } \\
\text { percobaan berkaitan dengan bunyi } \\
\text { secara berkelompok }\end{array}$ & Mencoba \\
\hline $\begin{array}{l}\text { Siswa diminta untuk berdiskusi } \\
\text { menemukan proses perambatan } \\
\text { bunyi }\end{array}$ & Menalar \\
\hline $\begin{array}{l}\text { Setiap kelompok diminta } \\
\text { membuat laporan kegiatan dan } \\
\text { mempresentasikan hasil } \\
\text { percobaan di depan kelas }\end{array}$ & Mengkomuni- \\
\end{tabular}

Berdasarkan tabel 2 di atas dapat disimpulkan bahwa pembelajaran di kelas 4 telah sesuai dengan kaidah pendekatan saintifik. Pembelajaran yang dilaksanakan guru dan siswa kelas 4 meliputi proses menanya-mempertanyakan, mengamati, mencoba, menalar-mencipta, dan mengkomunikasikan. Setelah guru dan siswa menyanyikan lagu "Tik-tik Bunyi Hujan", guru mengajukan pertanyaan tentang "Bunyi apa yang pernah kalian dengar?". Lalu siswa menjawab dan dilanjutkan dengan mengajukan pertanyaan kepada guru "Pak, apa yang dimaksud dengan sumber bunyi?". Ketika siswa menanyakan hal tersebut guru memberikan kegiatan supaya siswa dapat menemukan jawaban dari pertanyaannya itu sendiri. Kegiatan yang dilakukan oleh siswa adalah mengamati sumber bunyi yang ditunjukkan guru meliputi seruling dan gitar. Setelah itu, siswa diminta untuk memainkan sehingga menghasilkan bunyi. Supaya lebih memahami siswa diminta untuk membuat telepon sederhana dari gelas plastik dan seuntai benang, lalu siswa mencoba memainkan telepon sederhana serta menemukan bagaimana caranya bunyi dapat merambat melalui seuntai benang, dan terakhir siswa diminta untuk membuat laporan kegiatan dan menjelaskan hasil percobaan di depan kelas. Setelah itu guru membimbing siswa menyimpulkan bahwa 
sumber bunyi adalah benda atau alat yang menimbulkan bunyi dan gelombang bunyi memerlukan medium dalam perambatannya.

Proses berpikir ilmiah yang tergambar di atas terjadi disetiap kegiatan dan siswa sendiri yang melakukannya. Siswa sangat aktif dalam menemukan jawaban dari sebuah percobaan dan guru bertugas membimbing dan mengarahkan pembelajaran. Proses menemukan hasil percobaan ini merupakan salah satu bentuk usaha dalam berpikir secara ilmiah. Dengan tingkat berpikir di kelas 4 yang arah berpikirnya menuju pada praoperasional konkrit, melakukan percobaan adalah hal yang tepat. Terbukti siswa kelas 4 dapat menemukan proses perambatan bunyi secara mandiri. Sehingga dapat disimpulkan proses berpikir ilmiah juga dapat dilakukan oleh siswa kelas 4 Sekolah Dasar.

\section{Pembahasan}

Proses pembelajaran dengan mengimplementasikan pendekatan saintifik telah dilaksanakan dengan baik di SDN Tanjungrejo 1 . Terbukti dari dilaksanakannya lima metode saintifik (mengamati, menanya-mempertanyakan, menalar-mencipta, mencoba, dan mengkomunikasikan) baik dalam pembelajaran kelas 1 maupun pembelajaran kelas 4. Walaupun dalam pelaksanaannya tidak berurutan akan tetapi pembelajaran tidak terkesan kaku. Pada pembelajaran di kelas 1 dimulai dari menanya, mengamati, menalar, mencoba, lalu diakhiri dengan mengkomunikasikan. Pada pembelajarn kelas 4 dimulai dari menanya, mengamati, mencoba, menalar, lalu diakhiri dengan mengkomunikasikan. Hal ini telah sesuai dengan pendapat Akbar (2014: 1) yang menyatakan bahwa pola pikir ilmiah tersebut hendaknya tidak langsung diterima begitu saja oleh para guru dalam proses pengembangan kompetensi siswa sebab jika diterima secara kaku langkah-langkah berpikir tersebut akan menjadi begitu sempit dan kaku, sebab dimungkinkan bisa saja terjadi tidak harus berurutan (mengamati, mempertanyakan, menalar-mencipta, mencoba, dan mengkomunikasikan) demikian.
Metode menanya yang terjadi di kelas 1 siswa bertanya berkaitan dengan kegiatan di musim kemarau, sedangkan di kelas 4 siswa bertanya mengenai tentang sumber bunyi. Proses eksplorasi telah dilakukan siswa melalui pertanyaan. Siswa berusaha menggali informasi dari guru untuk memahami materi pembelajaran.

Metode mengamati yang terjadi di kelas 1 siswa diminta untuk mengamati gambar berlibur ke pantai dan menemukan benda apa saja yang ada pada gambar, sedangkan di kelas 4 mengamati sumber bunyi yaitu seruling dan gitar serta memainkannya. Proses memahami suatu materi telah dilakukan siswa dengan memanfaatkan indera yang dimiliki. Siswa kelas 1 memanfaatkan indera penglihatanya untuk menemukan benda yang ada pada gambar, siswa kelas 4 memanfaatkan indera pendengaran untuk menemukan sumber bunyi.

Metode mencoba yang terjadi di kelas 1 siswa diminta menggambar benda yang ada di musim kemarau, sedangkan di kelas 4 siswa diminta membuat telepon sederhana dari gelas plastik dan seuntai benang. Proses mencipta dilakukan dengan berbagai macam kegiatan, siswa kelas 1 dengan menggambar menciptakan suatu karya, siswa kelas 4 dengan percobaan menciptakan alat untuk menemukan konsep.

Metode menalar yang terjadi di kelas 1 siswa menyebutkan benda yang ada pada gambar, secara proses siswa berusaha menemukan benda dan menghubungkan dengan tempat yang ada dalam gambar. Proses menalar pada kelas 4 terlihat dari siswa yang berdiskusi menemukan proses perambatan bunyi, siswa mencoba menghubungkan perambatan bunyi dengan benang yang ditarik dan direnggangkan. Proses menalar terjadi ketika siswa berusaha menghubung-hubungkan beberapa informasi yang didapatkan. Menalar merupakan salah satu ciri berpikir ilmiah.

Metode mengkomunikasikan yang terjadi di kelas 1 siswa menjelaskan karyanya berupa gambar di depan kelas, sedangkan di kelas 4 siswa menjelaskan laporan hasil percobaan. Mengkomunikasikan karya yang telah diciptakan di depan kelas memerlukan 
kepercayaan diri yang tinggi. Siswa kelas 1 dan kelas 4 dapat menunjukkan kepercayaan dirinya, semua siswa bersedia maju ke depan kelas menunjukkan hasil karyanya serta menunjukkan di depan kelas. Kepercayaan diri juga merupakan salah satu ciri berpikir ilmiah.

Berdasarkan pembahasan di atas, dapat disimpulkan bahwa metode mengamati, menanya-mempertanyakan, menalar-mencipta, mencoba, dan mengkomunikasikan dapat meningkatkan keaktifan dan kemampuan berpikir ilmiah siswa. Meningkatnya keaktifan terlihat dari hampir seluruh kegiatan pembelajaran yang melakukan adalah siswa. Meningkatnya kemampuan berpikir ilmiah terlihat dari kemampuan siswa dalam menalar, menemukan, menciptakan, hingga mengkomunikasikan.

\section{KESIMPULAN DAN SARAN}

\section{Kesimpulan}

Berdasarkan hasil penelitian dan pembahasan mengenai implementasi pendekatan saintifik pada kurikulum 2013 di SDN Tanjungrejo 1 Malang, maka dapat disimpulkan bahwa: (1) pelaksanaan pembelajaran yang mengimplementasikan pendekatan saintifik ini sudah sesuai dengan kaidah-kaidah saintifik yang terdiri dari lima metode yaitu, mengamati, menanya-mempertanyakan, menalar-mencipta, mencoba, dan mengkomunikasikan, (2) guru kelas 1 dan kelas 4 sudah memahami bahwa dalam mengimplementasikan pendekatan saintifik disesuai dengan kebutuhan tidak harus berurutan (mengamati, menanya-mempertanyakan, menalar-mencipta, mencoba, dan mengkomunikasikan) agar siswa tidak merasa pembelajaran terkesan sempit dan kaku, (3) selain keaktifan, kemampuan berpikir ilmiah siswa kelas 1 dan kelas 4 juga meningkat, hal ini terlihat dari kemampuan siswa dalam menalar, menemukan, menciptakan, hingga mengkomunikasikan suatu karya, (4) tidak ada kendala dalam pelaksanaannya hanya kreatifitas guru yang sangat diperlukan dalam menciptakan pembelajaran yang mengimplementasikan pendekatan saintifik ini.

\section{Saran}

Berdasarkan kesimpulan di atas maka disarankan kepada guru dalam mengimplementasikan pendekatan saintifik disesuai dengan kebutuhan tidak harus berurutan (mengamati, menanya-mempertanyakan, menalar-mencipta, mencoba, dan meng-komunikasikan) agar siswa tidak merasa pembelajaran terkesan sempit dan kaku. Guru harus mengembangkan kreatifitas agar pembelajaran dengan mengimplementasikan pendekatan saintifik ini menjadi pembelajaran yang bermakna.

\section{DAFTAR PUSTAKA}

Akbar, S. 2014. Penyegaran Pembelajaran Tematik Berbasis KKNI Kurikulum 2013: makalah kuliah umum. Malang: Universitas Kanjuruhan Malang.

Kemendikbud. 2013. Kerangka Dasar dan Struktur Kurikulum 2013. Jakarta: Kemendikbud.

Kurikulum. 2013. Lampiran Peraturan Menteri Pendidikan dan Kebudayaan Nomor 65 Tahun 2013 tentang Standar Proses Pendidikan Sekolah Menengah Pertama/Madrasah Tsanawiyah. Jakarta: Kementerian Pendidikan dan Kebudayaan. Marchin, A. 2014. Implementasi Pendekatan Saintifik, Penanaman Karakter dan Konservasi Pada Pembelajaran Materi Pertumbuhan. Jurnal Pendidikan IPA Indonesia: JPII 3(1) (2014) 28-35.

Moleong, L. 2011. Metodologi Penelitian Kualitatif. Bandung: Remaja Rosdakarya.

Sugiyono. 2010. Metode Penelitian Pendidikan Pendekatan Kuantitatif, Kualitatif, dan $R \& G$. Bandung: Alfabeta.

Sudrajat, Akhmad. 2013. Pendekatan Saintifik Ilmiah dalam Proses Pembelajaran. (online),(https://akhmadsudrajat.wordpress .com/2013/07/18/pendekatansaintifikilmiah-dalam-prosespembelajaran,diakses tanggal 1 April 2014. 